\title{
British Justice
}

\author{
Pearl Duncan
}

\section{Preamble}

I was very pleased to be asked to contribute to a special edition of Aboriginal History in honour of my dear friend and mentor, Isobel (Sally) White. Sally befriended me when I first went to Canberra as a member of the National Aboriginal Education Committee and later when I studied anthropology at the Australian National University.

We kept in touch over the years and whenever I visited Canberra she always provided a bed for me. I was a grateful recipient of her kind hospitality and her unstinting generosity in sharing with me her great wealth of knowledge, her wisdom and her extensive anthropological library.

Sally often prevailed upon me to write an article for Aboriginal History. I always promised to consider it but somehow it was always difficult to find the time. In reality my full-time university jobs, thesis research and writing and my membership of various committees made huge demands on my time and energy.

I remember once saying to Sally, 'But what shall I write about given the limited time that I have to spare?' She replied, 'Pick something easy and familiar such as your mother. Why not write about her?' I had told Sally many anecdotes about my mother. So here it is Sally! I have finally written about my mother who was a great influence in my life.

\section{My mother}

My mother, who was descended from New England people, was a very strong, forthright woman who did not 'kowtow' to anyone; neither did she suffer fools gladly. She always spoke her mind without fear or favour, having strong views about most things, especially her rights as a human being.

My mother was reared by her maternal grandparents. Her mother, always sickly and delicate, had a baby every twelve months. Some of these babies died, but, surprisingly, eleven of them grew into adulthood. It is not surprising, however, that my mother's mother died in childbirth by the early age of 37 . Before her untimely death, my mother and one of her sisters were fostered by their grandparents. This was to relieve the pressure of feeding two extra mouths at home.

Her elderly great-grandfather, Henry Harrison, who was an Englishman from Warwickshire, also lived with my mother's maternal grandparents. Having committed a minor offence by today's standards, he had been transported to Australia as a convict. 
He lived to the great age of 96 , and when he died, he was the last convict in that area. His obituary was written in the local newspaper of the time. Great-grandfather Harrison appears to have been a very patriotic Englishman who never forgot his homeland and entertained my mother with stories, songs and poems of England. He impressed upon my mother that the British Empire was the greatest empire in the world.

When I was a child, my mother often remarked to me that the sun never went down on the British Rmpire. She taught me the poems and songs that her great-grandfather had taught her. One of the poems, if I remember correctly, said 'Only an old bit of bunting, only an old coloured rag, but many have died for its honour and laid down their lives for the flag'. I attended school during the years of World War II when there was a lot of patriotism around. I was good at recitation and was often the star performer in front of the class. The teacher and the pupils always prevailed upon me to say the above-mentioned poem. I always stood willingly at attention as I proudly and willingly obliged.

Henry Harrison was a devout member of the Church of England, known now as the Anglican Church of Australia. He said his daily offices of Matins and Evensong and read his Bible every day. My mother often wondered if he had received some theological training sometime during his life in England. Unfortunately we will never know because my mother would not have known what sort of questions to ask him when she sat at his knee as a small child. In any case, my mother was brought up in the faith of the Church of England to which she devotedly remained faithful for all of her life. My last duty to her as a loving daughter was to ensure that she received the last rites of the Anglican Church before she departed this life.

My mother excelled at school. She passed the qualifying certificate (QC), which was a very impressive examination at that time. It enabled one to become a pupil teacher, who would then serve an apprenticeship under the supervision of a headmaster. After a year at teacher's training college, the pupil teacher could then become a fully qualified teacher who could be in charge of a class.

Unfortunately my mother had to leave school at age 14 to earn her living by entering domestic service, which was the only option left for an Aboriginal girl at that time. Domestic service was virtually slave labour in those days. Live-in domestics worked from dawn to dark, beginning their day's work by lighting the kitchen fire and then serving morning tea on trays to all members of the household. This would be the wakeup call for the men of the household, who would be off to do farm work and then return to a hearty cooked breakfast at about 7:30 a.m. This was a hard day's work before the day had really begun, but there followed morning tea, lunch, afternoon tea and dinner at night, along with the laundry and general housework. There was no respite until the household was served supper and the kitchen left spotless; then and only then was the rest of the evening free for personal chores. When my mother returned to domestic service after she and my father separated, this brief time in the evening was when she sat up late sewing clothes for us. We were then in the care of her eldest sister, our aunt Min.

It is mind-boggling to think that people like my mother were simply beasts of burden enduring all kinds of indignities for the sake of providing for their children. Remember, there were no labour-saving devices, no conveniences or single parent pen- 
sions. It was all back-breaking, relentless hard yakka and there was no light at the end of the tunnel. If any good came out of the hard work and dreadful deprivation it was that my mother became an excellent cook and proficient in all domestic work, including sewing and knitting. But I find it poignant that she also assumed middle-class attitudes.

Our mother took over our upbringing after an absence of about four years. She did domestic work around town for various people and returned home every night. The work was not easier. The employers made sure that they got more than their money's worth out of her.

She was very strict about our upbringing. We were taught to be well-mannered and polite and to be careful of the friends with whom we associated, especially white kids. She was always suspicious of them until she was satisfied that they were all right. In those days it was common to think that if whites mixed with Aborigines there must be something amiss or unacceptable in their characters.

We could not read anything that she thought was unsuitable. I often received a long lecture if she caught me reading True Romances, a magazine that my young aunts had passed on to me. She argued that I would get the wrong idea of life and 'real life' was not like the one True Romances portrayed. It was not unusual for her to throw this type of literature into the fire. Also, she would not allow us to read about murder or violence in the newspapers. The only ones we had access to were those that were wrapped around our groceries or the ones passed on to my mother by the people she had worked for, many days after they had read them.

We had to be truthful and stand up for our rights if we were wrongfully accused. Unfortunately this happened often. Honesty was the best policy. Stealing was forbidden and respect for other people's property was instilled into us at an early age.

My mother liked to emulate the well-educated, well-bred whites. Refinement was a word she frequently used and looked for in people, especially her employers. She despised what she termed 'low class whites' for what she perceived as sloth, ill breeding, low moral standards and ignorance. In retrospect she was more 'royal than the royal' as it were. But she did recognise that there were many good, honest, decent poor white people in the same way that there were many unsavoury ones from the middle and upper classes.

Table manners were very important to my mother, especially if we were invited to eat in the homes of white people. Although we came from a very humble home, it was vital for us to know how we should conduct ourselves outside. Cleanliness was a given. Our home was no better than a shack, but it was spotless. Having to fetch water from the river did not deter us from keeping up our standards. Consequently, my mother was very critical and disapproving of the homes and the habits of some of the people she had worked for or who had befriended her.

I remember that my mother was a good storyteller. She had an amazing memory and a wonderful gift for words. She brought us up on a diet of stories that had strong moral elements. Those stories were European cautionary tales, but the very act of her using them to teach us valuable lessons in life must have surely hearkened back to the traditional past when her ancestors were great orators and storytellers. My most treasured memories of my childhood take me back to those times we spent around the fireside listening to our mother's stories. 
My mother told me many times that she regretted not listening to her grandmother in order to learn the language of the old people. That means that even her own mother had lost the language and the culture of her clan. It is sad to think that the languages were endangered so early during the white settlement of the New England District of New South Wales. However, my mother did pick up odd words and phrases of her lost language, and, although there was little if any of the high culture left, she possessed a wealth of folklore.

She was a strong believer in the supernatural and in what she called 'warnings and signs from the other side.' She believed in the 'death bird' and taught us to do the same. It was never wrong. Whenever we heard its blood-curdling, indescribably chilling call, it was certain that soon we would have news of the death of a close relative.

Raising us in the 1940s our mother worked hard at soul-destroying domestic tasks that, even for those days, paid a pittance. She had to be most frugal with the small amount of money that she had at her disposal. She weighed every penny and thought hard about parting with it. If anyone needed something, they had to save up for it. There was no easy access to credit or to hire purchase in those days. One of the tasks I had to do was to go over all the food bills and check for mistakes. She never trusted the shopkeepers and always thought that they were robbing her. In the days of my childhood, decimal currency was unheard of, so we had to contend with pounds, shillings, and pence. Worst of all were the halfpennies; nevertheless, halfpennies counted. If I discovered that one halfpenny were overcharged, my mother would take the bill back to the shop and demand her refund. I must admit that I found these tasks tedious and was embarrassed when my mother confronted the shopkeeper, but now I think how courageous she was for standing up for her rights. It was not easy for Aborigines at that time to be outspoken and fearless in a white-dominated society.

My mother believed that there was no system as good as the British one, that the British Empire was great, and that it meant freedom for all of its subjects. Those who lived under the Union Jack enjoyed good, solid British justice and proudly affirmed their allegiance to British values. I suspect that her great-grandfather Harrison and the landed gentry in whose homes she had slaved had a lot to do with indoctrinating her.

Recently my brother asked me if I remembered when Mum went to the school and demanded 'British justice?' I did remember and we laughed as we reminisced, going over every detail of the event with tears streaming down our cheeks. I shall always remember that day and how my mother conducted herself. We had been getting into trouble at school by being wrongly accused of various offences, and after listening to our complaints, she was certain that we were being victimised. So she jammed her old hat on her head (she always wore a hat to town), shoved her worn handbag under her arm and strode off to confront the headmaster with us in tow. The headmaster, who was known to be a bully by everyone including the white parents, said, 'Yes, Mrs. Duncan, what can I do for you?' Our mother stamped her foot, clenched her fists, and said in a forthright voice, 'I'm here for British justice!' The headmaster was speechless as he looked at her in disbelief, stunned amazement or stupidity for a good three minutes before regaining his composure. The matter was sorted out eventually and we left feeling we had achieved a modicum of success. 
My brother and I talked in fondness of our mother and smiled in pity for her undying faith in British justice. We wept as we reminded ourselves just what 'so-called British justice' had done for other Aborigines and for us. We wept for the pain and anguish it caused our mother, our other loved ones, and those dear, good people of our childhood who were so gentle and forbearing, but most of all, so forgiving. British justice may have prevailed for the white people but there was no justice for us. I doubt if there was justice for the other Indigenous people whose lands were stolen and whose cultures were destroyed by the spread of the British Empire throughout the world.

My mother accepted the myths and lies perpetuated by the white invaders and rulers. She was thoroughly indoctrinated at school and in domestic service for the landed gentry. Her great-grandfather, whom she loved, played a part too by inspiring her to venerate the British Empire and thus making her vulnerable to persuasion.

My mother asked for British justice but, in reality, did not get it. In fact, complete justice for Aborigines is still a burning issue in Australia and has to be fully addressed. The widely touted 'mateship' as proclaimed by the present Prime Minister, John Howard, may yet become a reality if 'mateship' truly means a fair go for all. But there has to be reconciliation and reconciliation can only take place with humility. The government must humbly apologise; it must say that it is sorry, and we must forgive, if that is appropriate. It is simply not possible to go back and to reverse all the wrongs that have been done to Aborigines in the past, especially where there is a legal system that ratifies those things. Saying sorry is not hard and is possible.

My mother's demands for 'British' justice may yet be realised if 'mateship' means what it is claimed to be.

Pearl Duncan is an educationalist. She was the first Aboriginal person to become a trained teacher, and subsequently taught for many years in Queensland (including the Torres Strait Islands) and New South Wales. More recently she has taught Aboriginal Studies at the Southern Cross University and later at the Queensland University of Technology, where she was head of the Aboriginal and Torres Strait Islander unit. She is currently working on a doctoral thesis on Aboriginal humour at the University of Queensland. 